\title{
A Sheep Production System for Milk in The Izta-Popo Region
}

\author{
L. Luna Rodríguez ${ }^{1}$, H. R. Losada Custardoy ${ }^{1}$, J. Cortés Zorrilla ${ }^{1}$, J. M. Vargas Romero ${ }^{1}$, V. Alemán López ${ }^{1}$, J. E. Vieyra \\ Durán $^{1}$, A. B. Vicuña Guerrero ${ }^{2 *}$, G. A Moreno García ${ }^{2}$, F. L. Bartolo Reyes ${ }^{2}$ \\ ${ }^{1}$ Universidad Autónoma Metropolitana-Unidad Iztapalapa, Área de Sistemas de Producción Agropecuarios, Avenida San Rafael Atlixco 186, Colonia \\ Vicentina, 09340 Iztapalapa, Ciudad de México, México \\ ${ }^{2}$ Universidad Autónoma Metropolitana-Unidad Iztapalapa, Licenciatura en Producción Animal, Av. San Rafael Atlixco 186, Leyes de Reforma 1ra \\ Secc, Iztapalapa, 09340 Ciudad de México, CDMX, Mexico
}

DOI: $10.36348 /$ sb.2020.v06i01.005 $\quad$ | Received: 13.01.2020 | Accepted: 20.01 .2020 | Published: 29.01 .2020

*Corresponding author: Alma Brenda Vicuña Guerrero

\section{Abstract}

Sheep's milk (Ovis aries) is mainly produced in Asia (45.6\%), with notable quantities in China and Turkey, followed by Europe $(29.0 \%)$, Africa $(24.5 \%)$, Oceania $(<0.1 \%)$ and in North and South America $(0.9 \%)$, the latter area is reported to be increasing. In Mexico, sheep production systems for dairy purposes are poorly understood, because the population usually consume milk and dairy by-products of bovine origin; and those of goat and sheep origin consume it little. However, sheep milk production has potential; first, promoting diversification in production; second, as a promising increase in profits of the farmers (conquest of consumers of demanding palates and with high purchasing power); and third, align with new trends and modify food production to more natural systems (environmentally friendly) that harmonize with agricultural production, which promote bio diversity. This study aims to describe the model of the Livestock Production Unit- (LPU) located in the Volcanoes region. Alternative model to produce milk and cheese of sheep origin found in the facilities of the -Centro para la Sustentabilidad de la Sierra Nevada- 'Incalli Ixcahuicopa' (CENTLI); which belongs to the -Programa de Investigación Sierra Nevada- (PISN) of the Universidad Autónoma Metropolitana (UAM). The sheep in this LPU are of the East Friesian breed and the choice was because it is a dairy breed par excellence and that ensures a higher yield of milk transformed into cheese. The sanitary and reproductive management carried out in this productive unit is optimal to achieve the production standards of the breed using local food resources.

Keywords: Flock, Handmade, East Friesian, Sustainability, Mating, Livestock production unit.

Copyright @ 2020: This is an open-access article distributed under the terms of the Creative Commons Attribution license which permits unrestricted use, distribution, and reproduction in any medium for non-commercial use (NonCommercial, or CC-BY-NC) provided the original author and source are credited.

\section{INTRODUCTION}

FAOSTAT [1] reports that sheep's milk (Ovis aries) is mainly produced in Asia (45.6\%), with notable amounts in China and Turkey, followed by Europe $(29.0 \%)$ and Africa $(24.5 \%)$. In addition, there is a very small but growing production in North and South America $(0.9 \%)$ and in Oceania $(<0.1 \%)$. Sheep production systems provide an important source of milk in countries where fodder and grains are insufficient to feed cows. This is how the search for alternative agricultural income has revived interest in sheep production in northern Europe, Australia, India, New Zealand and the United States. Other attractive features of milk-producing sheep breeds (Awassi, East Frisona and Lacaune) are low capital investment, low land requirements, high profit margins per liter and lack of production quota limits [2-4].
Considering that the agri-food sector requires competitive production systems [5] sheep milk production in Latin American countries could be considered as a possibility to obtain greater benefits [6]. In addition, sheep milk can be used as a vehicle for rural development, job creation and to curb the migration of the rural population.

Particularly in Mexico the production of sheep milk is a little known activity but with a high potential-, due to three relevant points: a) the growing need to diversify production, b) the conquest of new markets (consumers of demanding palates and with purchasing power) and c) be in line with new trends in food production in natural systems (environmentally friendly) that harmonize with agricultural production, 
which promote biodiversity. The above is a challenge to produce profitably; then, it is when in the search for new livestock options a promising alternative is the production of sheep's milk mainly destined to cheese making. Therefore, it is important to study these productive systems, the purpose of this work is to describe the model of the -Livestock Production Unit(LPU) located in the Volcanoes region.

\section{METHODOLOGY}

\section{System Survey}

In this stage the elements of the productive system were clearly identified, this implies describing the processes with which the system works. In this sense it is very important to emphasize that what interests us are the actual processes used by the staff. The survey was carried out in a top-down manner, this implies starting with a simple and thick scheme of the production chain and then detail the processes by consulting internal documents, interviewing staff and observing the system working.

\section{Production System Location}

The LPU which is located at the geographical coordinates, latitude $19^{\circ} 12^{\prime} 32^{\prime \prime} \mathrm{N}$ and longitude $98^{\circ}$ $47^{\prime} 01$ " W, $300 \mathrm{~m}$ from the San Rafael road and approximately $42 \mathrm{~km}$ from the Popocatépetl and Iztaccíhuatl Volcanoes in the municipality of Tlalmanalco, state of Mexico, Mexico; within the facilities of the -Centro para la Sustentabilidad de la Sierra Nevada- 'Incalli Ixcahuicopa' (CENTLI), This center belongs to the -Programa de Investigación Sierra Nevada- (PISN) of the Universidad Autónoma Metropolitana.

\section{Agroecological Characteristics}

The municipality in which the LPU is located has an altitude of 2,300 $\mathrm{m}$ [7] and in a sub-humid semicold climate, with summer rains and annual rainfall of $1,092 \mathrm{~mm}$, with an average annual temperature of 13.2 ${ }^{\circ} \mathrm{C}$. In addition, there are 4 types of soils: lithosols, andosoles, cambisols and flurisols; and the vegetation is pine-oak and pasture forest [8].

\section{RESULTS AND DISCUSSION Production System Description Installations and their relationship with sheep management \\ The surface is divided into pens to separate the} herd according to the physiological and developmental stage, or productive end. The section that houses the animals is surrounded by wire, in each division it has 2 feeders and 1 galvanized foil trough (Figure-1). The facilities are roofed and the floor has a straw bed that is constantly cleaned.

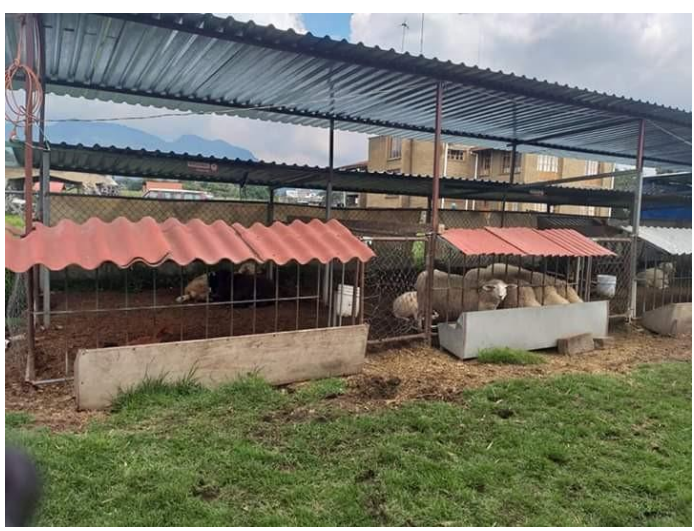

Fig-1: Livestock Production Unit of the CENTLI

Adult sheep after parturition, are housed together with their young for 1 month, to allow breastfeeding. In this section there is a feeder where the lambs are provided with feeding initiat (creep feeding) (Figure-2). When the lambs are weaned, they are passed to another pen, if they are females, they are taken care of so that they have adequate development and growth to be part of the herd, when they are male they are sold at weaning or they are taken to the end for meat production (Figure-3).

Also, there are spaces for shearing wool, quarantine section and an area for milking; the latter is close to the sheep pen and includes a wooden platform adapted to facilitate handling with adequate sanitation. On the other hand, there are storage areas for the food of the sheep, areas to protect the work material, tools and equipment, warehouses for the medicine and production records.

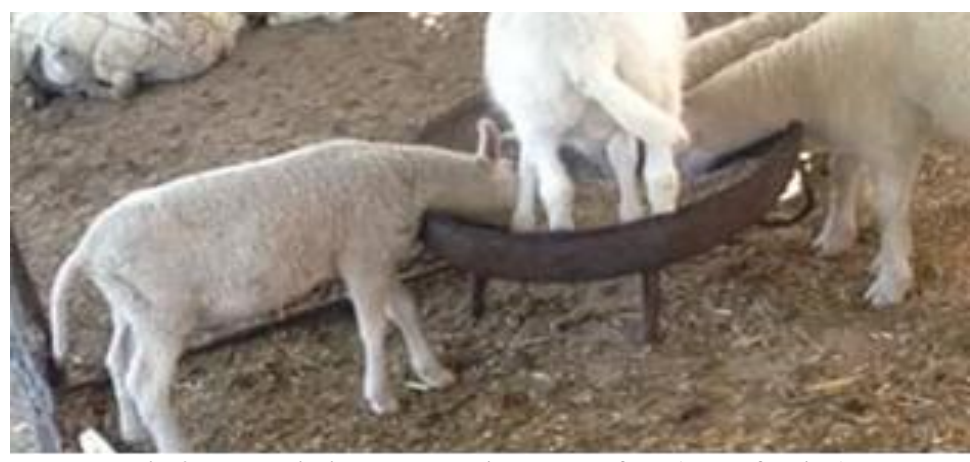

Fig-2: East Friesian lambs eating starter feed (creep feeding) 


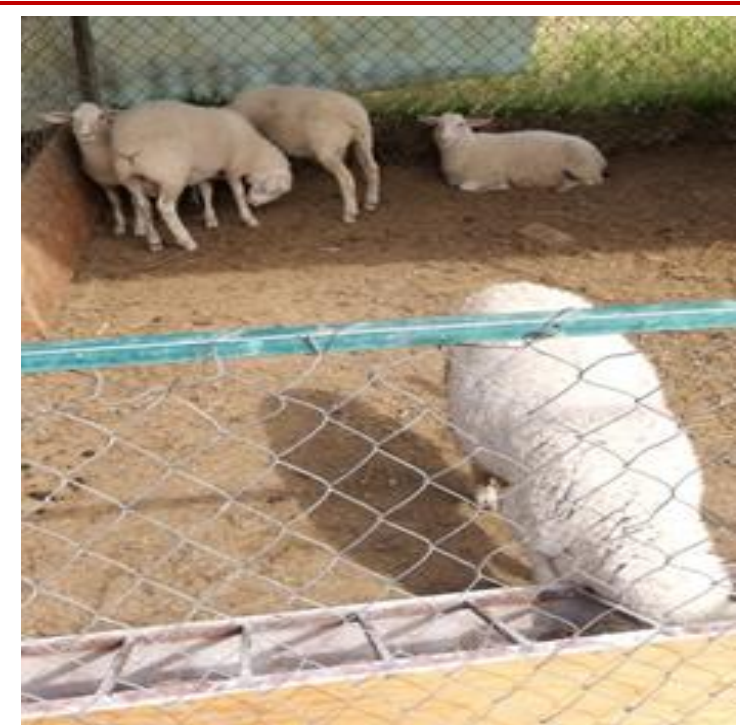

Fig-3: Female and male lambs East Friesian under development

\section{Genetic Resources}

The sheep is a diverse species with great genetic variability in physiological characteristics, fertility and muscle development [9]. He herd of the LPU is formed by animals of the breed native to the provinces of Friesiand in Holland and East Friesian in Germany, this is known as the best milk producer, has an udder of excellent conformation and adapted to milking [10], is possible to obtain between $700-1,000$ L / 220 - 250 lactation days.

It is a breed of large animals, males reach a weight of 90 to $120 \mathrm{~kg}$ and females of 80 to $100 \mathrm{~kg}$, animals with wool production and without horns; the head, legs, tail and udders are bare and are generally white, although there are blacks (Figure-4) and white with brown spots, with a pink nose. They are very fertile and prolific, they are not seasonal, and they can give birth between 14 and 16 months of age and have a good maternal instinct [11].
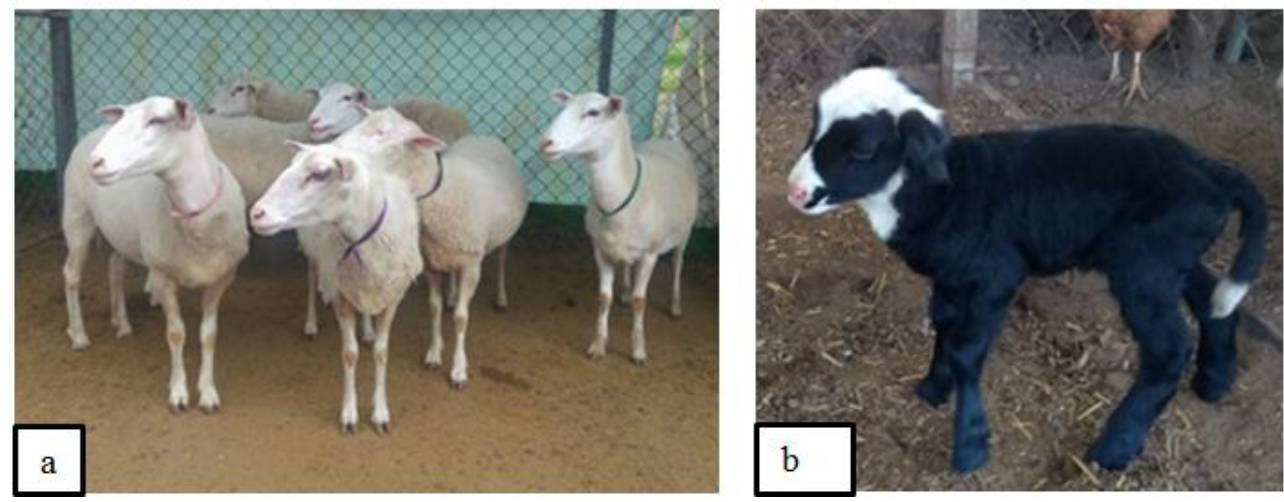

Fig-4: a) Sheep in the CENTLI Livestock Production Unit and b) a nursing lamb of the East Friesian breed

\section{Identification and Health Management}

For this LPU each animal was registered in the SINIIGA (Sistema Nacional de Identificación Individual de Ganado) and there is an individual control-register, where each activity carried out with the animal is programmed and written in detail (births, date of birth, weight, weaning, medication, vaccination and other zootechnical activities). On the other hand, records of lactation, the beginning, quantity of milk and end of milking (productive and reproductive variables) are managed.

As for vaccination, lambs are immunized with a combined vaccine that provides protection against enterotoxemia and tetanus. Likewise, sheep receive the same vaccine before delivery to transmit passive immunity.

The herd was taken a sample to obtain the certification of healthy, being carried out within the framework of the National Campaign against Brucellosis in animals, (dictum: Brucellosis free herd). He herd is routinely treated by internal parasites by means of antiparasitic (ivermectin subcutaneously) and the control of external parasites (infusion with medicinal herbs) a solution that is sprayed on the body of the sheep. The remove hoof, and foot bath is done to avoid any infection and the wool is sheared annually (Figure-5). 

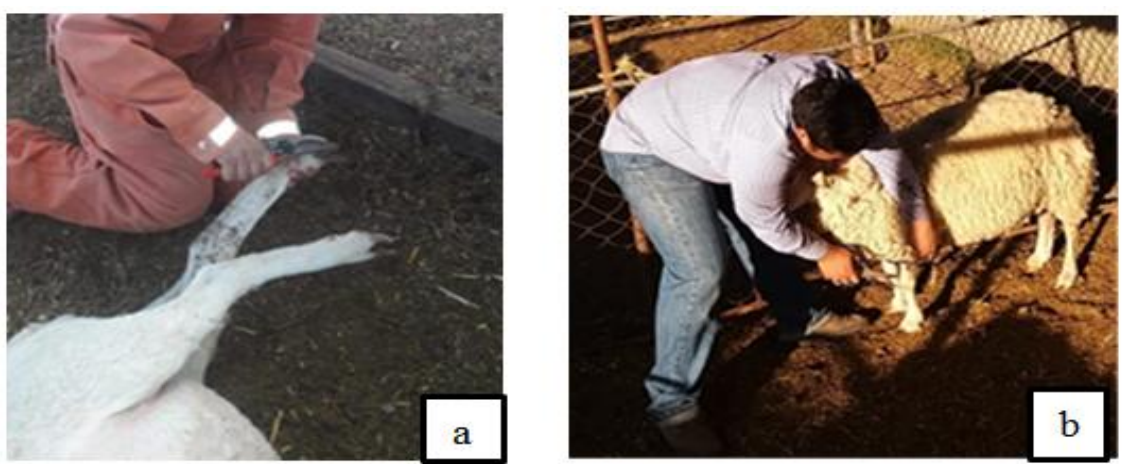

Fig-5: a) Remove hoof and c) sheared wool

In production systems it is necessary to have proper sanitary management to avoid the presence of diseases, ensure proper feeding, vaccination programs, ventilated and hygienic facilities; the latter, because the main diseases of the respiratory system, and sometimes infections in the extremities are caused by excess moisture in the pens [12].

On the other hand, at the LPU special care is taken to ensure that lactating sheep are not given any medication that can contaminate the milk. They are also routinely monitored (Figure-6) with the California Test for the detection of subclinical mastitis.

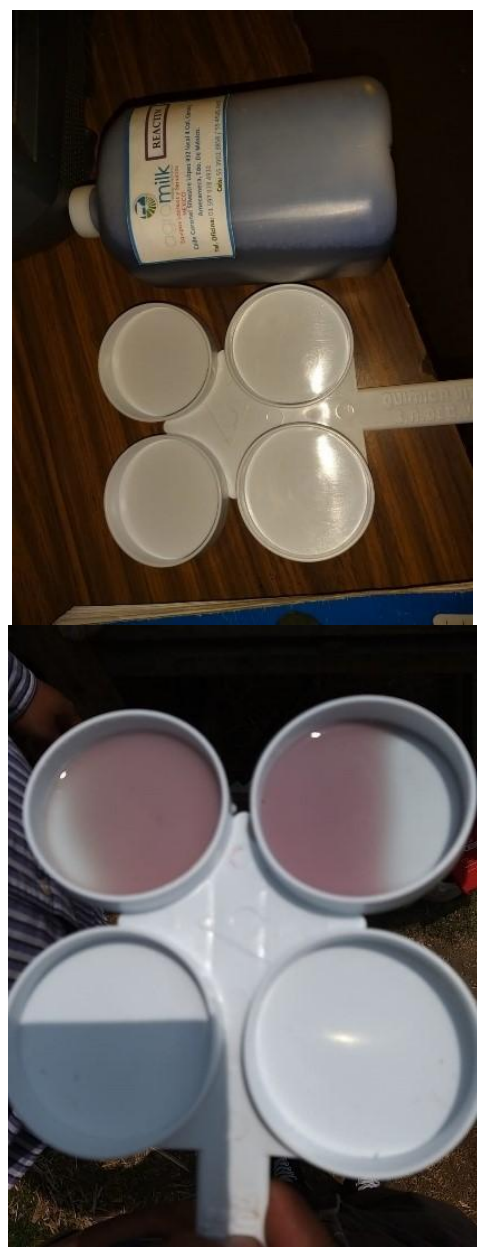

Fig-6: California test for the detection of subclinical mastitis
Livestock identification is essential (Figure-7), in order to have a record of ownership and management or to know its path through the production chain (traceability) [13]. The SINIIGA, in collaboration with the identification technician, is the one in charge of assigning a number, providing and placing the identification earrings for the animals that are in this productive unit.

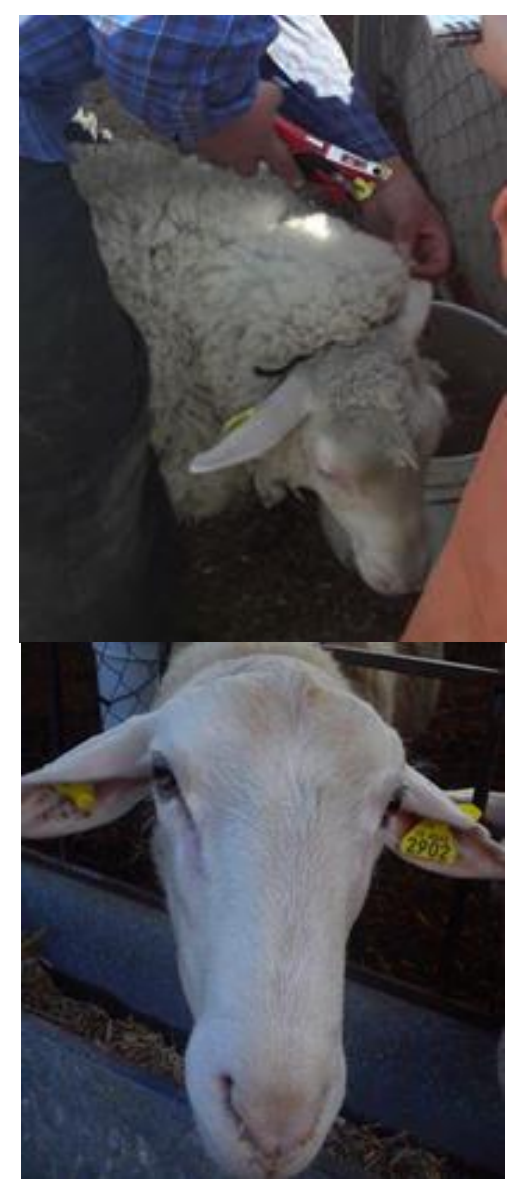

Fig-7: Identification of the National System of Individual Identification of Livestock

\section{Nutrition}

In the nutritional needs of sheep is consider a daily demand for water, energy, proteins, minerals and vitamins, to maintain adequate growth, production and reproduction. However, these needs vary according to 
the production system, the physiological state (mating, phases of pregnancy, lactation, and maintenance), sex, age and live weight [14].

In this LPU the diet supplied to animals is based on abundant forages of good quality that are complemented with grains, protein sources and minerals; the diet is prepared according to the needs of the herd.

\section{Reproductive Management}

In this productive unit, mating is programmed annually and it is done in July to have parturitions in January. A strict mating calendar is maintained, to ensure the production of both milk and cheese.

To guarantee the productive end that is sought, there are currently different techniques that can help increase reproductive efficiency, such as, the appropriate selection of replacement females, the correct determination of the reproductive season, early weaning, diagnosis of pregnancy and the use of production records, to mention a few [15].

\section{Lactation (Milking)}

The LPU has adequate zootechnical care to produce milk under the strictest quality standards and in a sustainable way. This system takes advantage of the fact that sheep milk production has a series of comparative advantages in relation to the production of bovine milk [16]. As is known, the high content of protein, fat and total solids in milk are associated with high yields in dairy products, so sheep milk has a higher cheese yield compared to cow or goat milk [17].

This LPU also produces artisanal sheep cheeses of excellent quality and in a sustainable way. The only way to get a good cheese is to start with milk from healthy animals, with a milk with composition and physical-chemical, organoleptic and hygienic-sanitary characteristics [18]. Is manually milking once a day, on average 1.5 to $2 \mathrm{~L}$ per day is collected, this milk is used immediately to transform it into cheese, acquired with rigorous techniques to ensure product safety final, obtaining a yield of $5 \mathrm{~L} / \mathrm{kg}$ of cheese.

\section{CONCLUSION}

The introduction of new breeds is a quick way to achieve changes in the racial constitution of existing animals in a country or region. In addition, when it comes to breeds with a productive orientation different from what is traditionally used, it can diversify the type of product obtained, both in primary form and in derivatives.

Considering that the animal resource available for the production of sheep milk in Mexico is limited by the lack of a sheep dairy tradition and that to achieve the success of the productive system the East Friesian are required spread it. Therefore, when it was introduced in this LPU the breed, it was carried out in confinement and with minimum cost diets based on the resources available in the Region, pending the establishment of grasslands.

\section{ACKNOWLEDGMENT}

To the -Programa para el Desarrollo Profesional Docente- (PRODEP) for financing the project entitled "Modalities of sustainable livestock production and production of the Metropolitan Area of Mexico City" in support of new full-time teachers. Also, we thank the co-directors and staff of the -Centro para la Sustentabilidad- "Incalli Ixcahuicopa" (CENTLI) for the facilities provided.

\section{REFERENCES}

1. FAOSTAT. (2018). Food and Agriculture Organization of the United Nations (FAO) http://www.fao.org/faostat/es/\#home

2. Rami, T. K., Abdullah, A. Y., Rousan, L. M., \& Gonzalez, B. A. (2011). Sistemas de producción de oveja Awassi y rendimiento reproductivo: una experiencia del medio oriente. Revista Chapingo Serie Ciencias Forestales y del Ambiente, 17, 6375.

3. Thomas, L. D., Berger Y. M., McKusick, B. C., \& Mikolayunas, C. M. (2014). Dairy sheep production research at the University, Wisconsin, Madison, USA - a review. Journal of Animal Science and Biotechnology, 5, 1-22.

4. Barillet, F., Marie C., Jacquin, M., Lagriffoul, G., \& Astruc, J. M. (2001). The French Lacaune dairy sheep breed: Use in France and abroad in the last 40 years. Livestock Production Science, 71, 17-29.

5. García, D. L. K., Mantecón, A. R., Sepúlveda, W. S., \& Maza, M. T. (2012). Producción de leche ovina como alternativa de negocio agropecuario: modelo de producción en Castilla y León (España). Revista Mexicana de Agronegocios, 31, 6-18.

6. Kremer, R., \& Rosés L. (2016). Producción y composición de leche de ovejas FrisonaMilchschaf ordeñadas 1 o 2 veces diarias. Veterinaria (Montevideo), 52(204), 22-28.

7. INEGI. (2009). Prontuario de información geográfica municipal de los Estados Unidos Mexicanos Tlalmanalco, México, 1-9. http://www3.inegi.org.mx/contenidos/app/mexicoc ifras/datos_geograficos/15/15103.pdf

8. INAFED. (2010). Instituto para el Federalismo y el Desarrollo Municipal. SEGOB Secretaría de Gobernación. "Los Municipios del Estado de México".

http://www.inafed.gob.mx/work/enciclopedia/EM M15mexico/index.html

9. Luna, P.C., \& Alonso, M. R. A. (2014). Genes con efecto mayor sobre la fertilidad de ovejas. Revista Mexicana de Ciencias Pecuarias, 5(1), 107-130. 
10. Ramírez, R. E. (2012). Manual de Crianza de Ovino de Leche. Huaraz. CARE Perú, 1-44.

11. Aguilar, R. L. A. (2017). Reproductiva de ovejas Dorset importadas de Nueva Zelanda tratadas con dos niveles de eCG, inseminadas por laparoscopía. Tesis de Ingeniero Agrónomo Zootecnista: Universidad Autónoma del Estado de México Centro Universitario UAEM-Temascaltepec, 1-84.

12. Puente, G. J. (2010). Sanidad en los Ovinos. "Fondo De Fomento Agropecuario del Estado de Tamaulipas" Comité Estatal De Evaluación: SAGARPA, 1-71.

13. FAO/OMS (2004). Prácticas de identificación animal http://www.fao.org/tempref/docrep/fao/010/y5454 s/y5454s03.pdf
14. González, V., \& Tapia M. (2017). Manual de manejo ovino. Santiago: Instituto de Investigaciones Agropecuarias (INIA), 3, 1-156.

15. Alonso, G. J. I. (1981). Manejo de la reproducción en el ovino. Departamento de la Producción Animal: Rumiantes, Facultad de Medicina Veterinaria y Zootecnia, UNAM, 434-463.

16. Hernán, G. J. (1997). Fermento natural de leche: efecto de su empleo sobre la calidad de quesos de leche de oveja. Tesis de Ingeniero Agrónomo: Facultad de Agronomía, Universidad de Buenos Aires, 1-44.

17. Busetti, M. (2001). La calidad en la leche de oveja. Sitio Argentino de Producción Animal, 206-214.

18. Bain, I. (2007). Elaboración de Quesos Artesanales con Leche de Oveja. INTA Chubut. XXI, 208-211. 